\title{
Hybrid Phytase and Carbohydrases in Corn and Soybean Meal-Based Diets for Broiler Chickens: Performance and Production Costs
}

\section{-Author(s)}

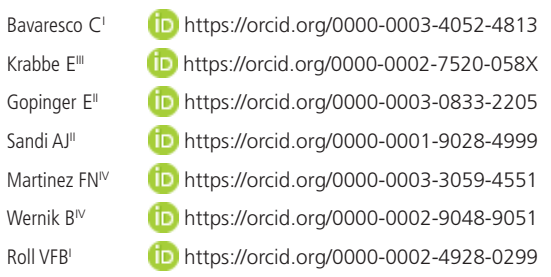

Federal University of Pelotas - Department of Zootechnics/ Av. Eliseu Maciel, s/n, Campus Capão do Leão/RS - Brazil.

Zootecnista. Doutora em Nutrição Animal.

III Embrapa Swine and Poultry. BR-153, s/n, Concórdia/SC, Brazil.

BASF S.A - Av. das Nações Unidas, 14171 Brooklin, São Paulo, SP - Brazil.

\section{-Mail Address}

Corresponding author e-mail address Caroline Bavaresco

Federal University of Pelotas - Department of Animal Science - Campus Universitário, s/n, Capão do Leão Pelotas 96010-900 Brazil. Phone: 53 3275-7274

Email: carolinebavaresco@hotmail.com

\section{aKeywords}

Calcium; cost; energy; enzyme; phosphorus.
Submitted: 04/September/2019

Approved: 13/January/2020

\section{ABSTRACT}

This study aimed to evaluate the effect of using $500 \mathrm{FTU} / \mathrm{kg}$ of hybrid phytase (created from three bacteria - Natuphos E), with or without xylanase and glucanase (560 TXU/kg; $250 \mathrm{TGU} / \mathrm{kg}$ ) - Natugrain $\mathrm{TS}$, in corn and soybean meal-based diets, with nutritional reductions in metabolizable energy (ME), $\mathrm{Ca}$, and available phosphorus (AP), on performance parameters and production costs in broiler chickens. The 1875 chickens were housed in boxes and distributed among 5 treatments with 15 replicates of 25 chickens each. The experiment included a positive control (the diet of which met the nutritional requirements of the birds), two negative controls (with ME reductions of 70 and 100 $\mathrm{kcal} / \mathrm{kg}$, and fixed reductions in $\mathrm{Ca}[0.16 \%]$ and $\mathrm{AP}$ [0.15\%]), and two treatments with identical nutritional reductions in addition to enzyme supplementation. The treatments included the following: $\mathrm{PC}=$ positive control (basal diet (BD) corn and soybean meal); $R_{-} 70=B D$ with reduction of $70 \mathrm{kcal} / \mathrm{kg}, \mathrm{Ca}$ and $\mathrm{AP} ; \mathrm{R} \_100=\mathrm{BD}$ with reduction of $100 \mathrm{kcal}, \mathrm{Ca}$ and $\mathrm{AP} ; \mathrm{R}_{-} 70+\mathrm{P}=\mathrm{BD}$ with reduction of $70 \mathrm{kcal} / \mathrm{kg}, \mathrm{Ca}$ and $\mathrm{AP}+$ phytase $(500 \mathrm{FTU} / \mathrm{kg}) ; R_{-} 100+\mathrm{P}+\mathrm{XG}=\mathrm{BD}$ with reduction of $100 \mathrm{kcal} / \mathrm{kg}, \mathrm{Ca}$ and $\mathrm{AP}+$ phytase $(500 \mathrm{FTU} / \mathrm{kg})+$ xylanase $(560$ $\mathrm{TXU} / \mathrm{kg})+$ glucanase $(250 \mathrm{TGU} / \mathrm{kg})$. Performance parameters, carcass yield, and production costs (USD/ton chilled carcass) were evaluated. In conclusion, the reductions of $70 \mathrm{kcal} / \mathrm{kg}, 0.16 \% \mathrm{Ca}$, and $0.15 \%$ AP did not affect performance in chickens over 42 days, if diets were supplemented with hybrid phytase (500 FTU/kg). Supplementation with hybrid phytase and carbohydrases in diets with reductions of $100 \mathrm{kcal} /$ $\mathrm{kg}, 0.16 \% \mathrm{Ca}$, and $0.15 \%$ AP led to lower production costs.

\section{INTRODUCTION}

In recent years, the costs of feeding broiler chickens have steadily increased, making the process of production less efficient. Corn and soybean meal account for about $80 \%$ of the nutritional matrix of broilers (Zou et al., 2013). Thus, fluctuations in the prices of these products greatly impact the total price of the diet. Supplementation of diets with lipids also increases feed costs, but it is often necessary to increase the energy content of the diets to meet the requirements of these birds. Moreover, diets need to be supplemented with phosphorus, owing to its low availability in plant-based foods. However, it increases feed costs and contributes to environmental pollution (Selle \& Ravindran, 2007; Woyengo \& Nyachoti, 2011).

Phosphorus is found in the seeds of some plants as a phytate (Maez, 2001).Poultry have a reduced ability to dephosphorylate $P$ from the inositol ring, owing to low production of the enzyme phytase in the body (Bedford, 2000).Thus, to increase the efficacy of dietary $P$, use of exogenous phytase is required. Another characteristic of plant-based diets that impairs nutrient utilization is the presence of 
Bavaresco C, Krabbe E, Gopinger E, Sandi AJ, Martinez FN, Wernik B, Roll VFB
Hybrid Phytase and Carbohydrases in Corn and Soybean Meal-Based Diets for Broiler Chickens: Performance and Production Costs structural carbohydrates, otherwise known as nonstarch polysaccharides (NSPs). Some of these NSPs increase intestinal viscosity because they are soluble and thus easily bind to water, effectively reducing the digestion rate by preventing digestive enzymes from accessing substrates (Bedford, 2000). Therefore, supplementation of poultry diets with carbohydrases would promote the cleavage of the NSP matrix found in cell walls (Meng \& Slominski, 2005; Lu et al., 2013), in addition to facilitating the access of other enzymes, such as phytase, to the substrate by exposing phytate (Juanpere et al., 2005).

In this regard, one of the strategies used by nutritionists is to reduce the amounts of some ingredients in the nutritional matrix. This is because the enzymes improve the efficiency of nutrient utilization and prevent food from being passed whole and/or being poorly exploited by the gastrointestinal tract (Zou et al., 2011; Romero et al., 2014). Moreover, new enzymatic products with distinct features that can lead to greater efficiency are released every year. This is the case with hybrid bacterial phytases, which have shown to improve the utilization of phosphorus and other phytate-bound nutrients (Torrallardona et al., 2017).

Although the use of phytase is relatively established, its supplementation in diets usually occurs based only on the valuations of $\mathrm{Ca}$ and $\mathrm{P}$, without the consideration of other nutrients. It can be said that this "uncertainty" is even greater when dealing with combinations of phytase and other enzymes.

Therefore, to benefit the poultry industry, it is extremely important to conduct studies that test the products available on the market, generating evidence that will help farmers make decisions regarding the specific nutritional matrix that should be adopted. Thus, this study aimed to evaluate the efficiency of a hybrid phytase supplemented alone or in conjunction with specific carbohydrases (xylanase + glucanase) in broiler diets containing nutritional reductions in metabolizable energy, $\mathrm{Ca}$, and available $\mathrm{P}$, in terms of performance and production costs.

\section{MATERIALS AND METHODS}

The experiment was conducted at the Experimental Poultry Department, Embrapa Swine and Poultry CNPSA, at Concordia, SC, Brazil. The project was approved by the Embrapa Animal Ethics Committee number 006-2017.

\section{Animals and Treatments}

A total of 1875 one-day-old Cobb 500 male broilers were housed in pens with pine shavings, equipped with tubular feeders, nipple-type drinkers (5/box), and electric hood heating.

The broilers had an average weight of $46.9 \mathrm{~g} \pm 3.7$ gand were randomly distributed among 5 treatments, with 15 replicates of 25 broilers each. The broilers were housed in boxes with dimensions of $1.65 \mathrm{~m} \times 1.70 \mathrm{~m}$ and a total area of $2.80 \mathrm{~m}^{2}$ (experimental unit).

The diets had different nutritional matrices and included a positive control diet (meeting the nutritional requirements of the broilers) and diets with $\mathrm{ME}$ (kcal/ $\mathrm{kg})$ reductions of $70\left(R_{-}\right.$70) and $100\left(R_{-}\right.$100) and fixed reductions of $0.16 \% \mathrm{Ca}$ and $0.15 \% \mathrm{AP}$, without or with the supplementation of a hybrid phytase [500 FTU/kg] - (R_70+P), xylanase [560 TXU/kg], and glucanase [250 $\mathrm{TGU} / \mathrm{kg}]\left(R_{-} 100+\mathrm{P}+\mathrm{XG}\right)$.

A previous study conducted with broiler chickens by Krabbe et al. (2014) tested the specific enzyme package containing xylanase and glucanase (Naturgrain TS) and found that there was a $32 \mathrm{kcal} / \mathrm{kg}$ increase in metabolizable energy in diets based on corn and soybean meal. The phytase energy matrix used in the present study $(500 \mathrm{FTU} / \mathrm{kg})$ predicts a gain of $68.9 \mathrm{kcal} /$ $\mathrm{kg} \mathrm{ME}$, and this information was used to determine the energy reductions $(70 \mathrm{kcal} / \mathrm{kg}$ and $100 \mathrm{kcal} / \mathrm{kg}$ ). The reductions of Ca\% (0.16) and AP\% (0.15) applied in the diet matrix also followed the manufacturer's recommendations.

\section{Enzymes}

Phytase. The phytase used (myo-inositolhexakisphosphate-beta-phosphohydrolase), Natuphos $E^{\circledR} 10,000$ G- [EC 3.1.3.26], BASF SA. is a granulated microbial phytase, and has a phytase activity of 10,000 $\mathrm{FTU} / \mathrm{g}$. Its activity in FTU is defined as the amount of enzyme that releases $1 \mu \mathrm{mol}$ of inorganic phosphorus/ min from $0.0051 \mathrm{~mol} / \mathrm{L}$ of sodium phytate at $\mathrm{pH} 5.5$ and $37^{\circ} \mathrm{C}$.

According to the manufacturer, this new molecule was created by manufacturing a hybrid phytase from three bacteria, which confers greater resistance to the product with regards to acid $\mathrm{pH}$ conditions, attack by endogenous proteases, and pelleting (up to $95^{\circ} \mathrm{C}$ ).

Carbohydrases. The carbohydrases used include endo-1,4-beta-xylanase and endo-1,4 beta-glucanase, Natugrain ${ }^{\circledR}$ TS - BASF SA - [EC 3.2.1.8] and [EC 3.2.1.4]. Both enzymes are produced from Aspergillus niger According to the manufacturer, the endoxylanase unit (TXU) is defined as the amount of enzyme that releases five micromoles of reducing sugar, measured as a xylase equivalent, per minute from a solution containing $1 \mathrm{~g}$ of arabinoxylan per $100 \mathrm{~mL}$ at $\mathrm{pH} 3.5$ and $40^{\circ} \mathrm{C}$. An 
Bavaresco C, Krabbe E, Gopinger E, Sandi AJ, Martinez FN, Wernik B, Roll VFB
Hybrid Phytase and Carbohydrases in Corn and Soybean Meal-Based Diets for Broiler Chickens: Performance and Production Costs endoglucanase unit (TGU) is defined as the amount of enzyme that releases one micromole of reducing sugar, measured as a glucose equivalent, per minute from a solution containing $0.714 \mathrm{~g}$ of beta-glucan per $100 \mathrm{~mL}$ at $\mathrm{pH} 3.5$ and $40^{\circ} \mathrm{C}$.

Enzymatic Activity. Enzyme activity assays were performed on the pelleted diets, which were collected and sent to CBO Analysis Laboratory, in Valinhos - São Paulo, Brazil.

For an expected dose of phytase of $500 \mathrm{FTU} / \mathrm{kg}$, the recovery ranged from 420 to $540 \mathrm{FTU}$. For a xylanase dose of $560 \mathrm{TXU} / \mathrm{kg}$, the recovery ranged from 517 to 579 units. For a glucanase dose of $250 \mathrm{TGU} / \mathrm{kg}$, the recovery ranged from 265 to 381 units.

\section{Feeding program}

The following four-phase feeding program was used: pre-starter (1-7 days), starter (8-21 days), grower (22-35 days), and finishing (36-42 days). The diets were pelleted $\left(80^{\circ} \mathrm{C}\right.$ for 20 seconds) and supplied after grinding in the pre-starter, initial, and growth phases, and were pelletized without grinding in the final stage. The composition and nutritional profiles of the experimental diets are described in Table 1.

\section{Variables analyzed}

Performance. The following variables were evaluated: mean body weight (BW), mean daily weight gain (DWG), feed intake ( $\mathrm{Fl})$, and feed conversion ratio $(F C R)$. The broilers were weighed on the day they were housed (day 1) and, then, weekly throughout the experimental period (up to 42 days). The feed provided and the leftovers were weighed weekly to determine the feed intake and the feed conversion ratio. Mortality was also recorded to correct performance data.

Carcass yield and Production costs. Two 42-dayold broilers that weighed $\pm 5 \%$ the mean weight of each experimental unit were selected to determine carcass yield. The animals were transported to a refrigerator with municipal inspection and slaughtered according to the current legislation for this type of establishment. The animals were weighed before slaughtering to determine the live weight. After evisceration and chiller cooling, the carcass was weighed to calculate the carcass yield using the equation: $C Y(\%)=$ (carcass weight $\times 100$ )/live weight.

The carcass yield was determined to calculate the cost per ton of cooled carcasses, following Miele et al. (2010).This methodology considers several stages and is based on the definition of the production system, the survey of technical production coefficients, and market prices (Protas, 1983; Girotto \& Protas, 1994; Girotto \& Santos Filho, 2000; Canever et al., 1996; Santos Filho et al., 1998; Girotto \& Souza, 2005).

The prices of the ingredients were quoted in September 2017 and converted to USD using the Ptax rate $(3,2659)$ on 09/14/2017 (Table 2).

\section{Statistical analysis}

The data were analyzed using analysis of variance (ANOVA), and the means were compared via Tukey's test using the LSM (least squares means) procedure. The analyses was performed at a significance level of $5 \%$ using the statistical package R (R Core Team, 2015).

\section{RESULTS AND DISCUSSION}

When considering the evaluated periods, there was no effect of the treatments on the mortality of the animals, 1 - 7 days $(p=0.29), 1-14$ days $(p=0.75)$, 1 - 21 days $(p=0.14), 1-28$ days $(p=0.18), 1-35$ days $(p=0.17)$, and $1-42$ days (0.46).

\section{Performance}

In the first week the main effect of the enzymatic supplementation was observed for FCR and showed results similar to those of treatment $\mathrm{PC}$ (Table 3 ).

A positive cumulative effect was observed for BW in animals receiving diets with enzymes from 14 days of age until the end of the experimental period (42 days). A similar pattern was observed for DWG from the second week of the experiment. In contrast, broilers receiving enzyme supplementation showed feed consumption results equivalent to those of the positive control group in all the evaluated periods (Table 3).The results of BW and DWG indicated that treatments with nutritional reductions ( $R_{-} 70$ and R_100) worsened the zootechnical indices, which could be reversed by enzyme supplementation ( $R \_70$ $+P$ and $R \_100+P+X G$ )

Assuming that the improvements in BW and DWG occurred due to increased nutrient availability in the diet due to the action of the enzymes, a reduced feed intake would also be expected (Kocher et al., 2003). Kocher and co-workers (2003) state that the use of carbohydrases leads to greater energy availability, resulting in a lower feed intake. However, this behavior was not observed in our study for broilers fed on the R_100 + P + XG diet between days 1 and 42 compared to the positive control. 
Bavaresco C, Krabbe E, Gopinger E,

Sandi AJ, Martinez FN, Wernik B, Roll VFB
Hybrid Phytase and Carbohydrases in Corn and Soybean Meal-Based Diets for Broiler Chickens: Performance and Production Costs
| 离 กิ

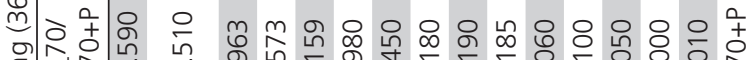

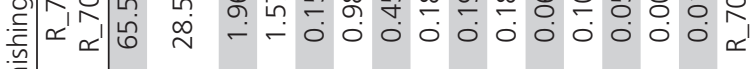

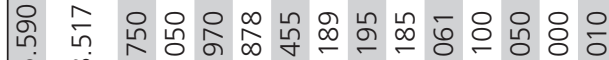

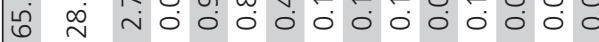

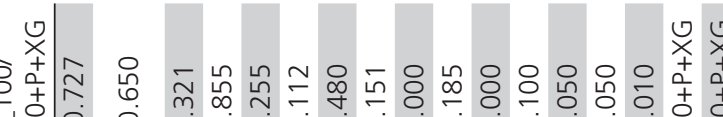

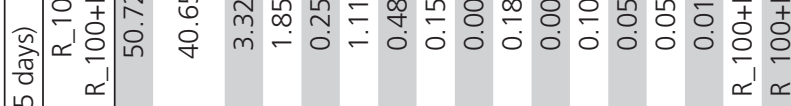

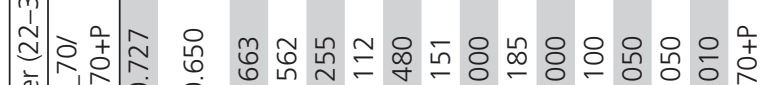

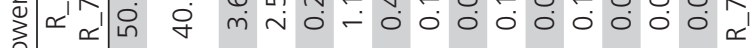
ஸे

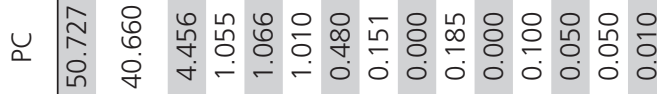

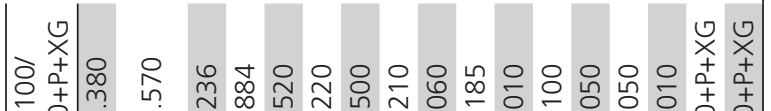

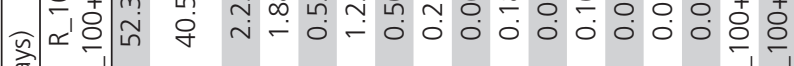

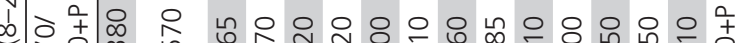

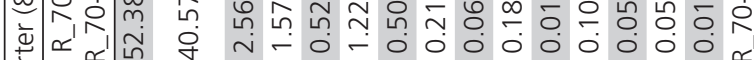

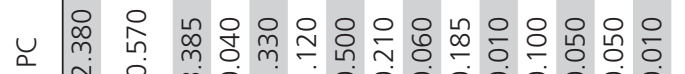

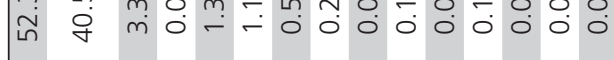

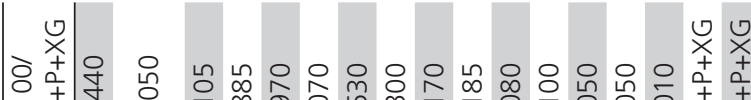

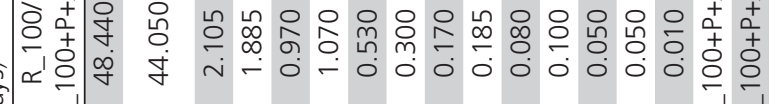

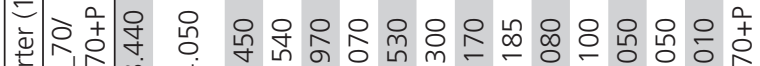

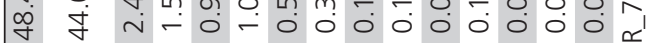

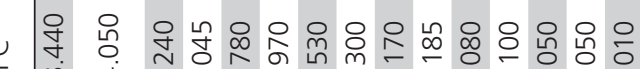
辛

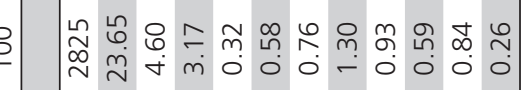

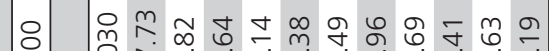
m

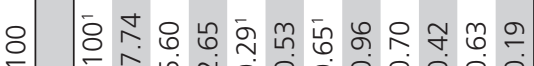
$m$
0
1

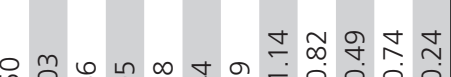

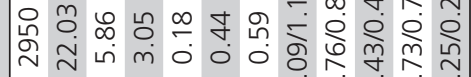
$\because \tilde{0}$ 。 An $\operatorname{d} \frac{1}{4}$

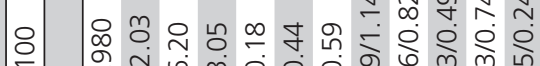
ฟิ 훗 m N

\section{$\frac{10}{20}$}

D N N $\begin{aligned} & \text { n m } \\ & 0\end{aligned}$

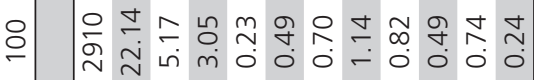

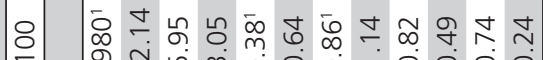
กิ

ㅇํำ

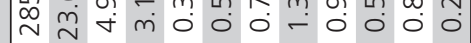

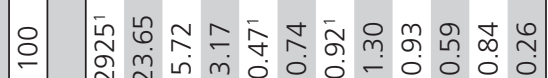

क

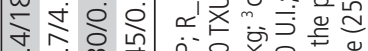
œ

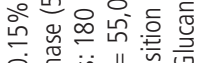

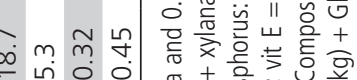

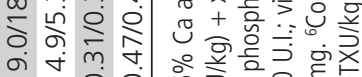
它

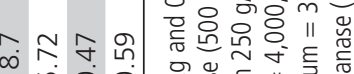

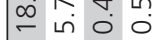
它总

o

$m$ m n ๙ิ ฟ

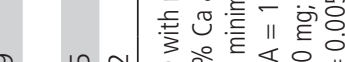
ㄱำ

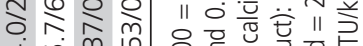
守 의은 ฟ 0 눈 는 ஸி மำ

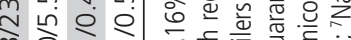
m ข ㅇ. 난 ขंن

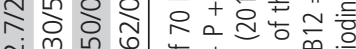
ฟ

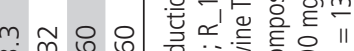

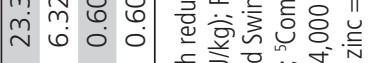

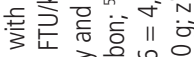

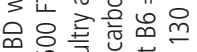

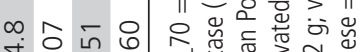

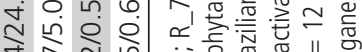
守先 N ナ. ㄴำ

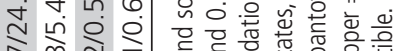

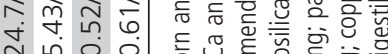

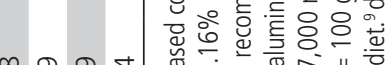
党管

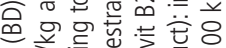

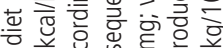

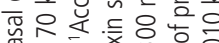

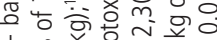

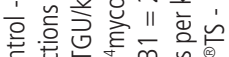

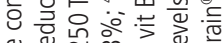

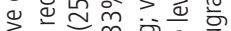

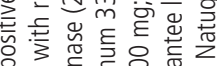

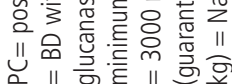




\section{Hybrid Phytase and Carbohydrases in Corn and Soybean Meal-Based Diets for Broiler Chickens: Performance and Production Costs}

Table 2 - Price in Brazilian Real (R\$) and US Dollars (USD) per $\mathrm{kg}$ of the ingredients used in the experimental diets.

\begin{tabular}{|c|c|c|}
\hline Ingredients & $\mathrm{R} \$ / \mathrm{kg}$ & USD $/ \mathrm{kg}$ \\
\hline Corn & 0.440 & 0.135 \\
\hline Soybean meal & 0.983 & 0.301 \\
\hline Soybean oil & 2.661 & 0.815 \\
\hline Kaolin & 0.440 & 0.135 \\
\hline Dicalcium phosphate & 2.459 & 0.753 \\
\hline Limestone & 0.179 & 0.055 \\
\hline Salt & 0.329 & 0.101 \\
\hline DL-Methionine & 13.75 & 4.213 \\
\hline L-Lysine & 6.469 & 1.981 \\
\hline Notox & 23.63 & 7.238 \\
\hline L-Threonine & 8.109 & 2.483 \\
\hline Vitamin premix & 14.86 & 4.553 \\
\hline Mineral premix & 6.828 & 2.091 \\
\hline Monensin sodium (Coban) & 31.86 & 9.758 \\
\hline BHT & 17.97 & 5.505 \\
\hline Phytase 500 FTU/kg & 48.98 & 15.00 \\
\hline Xylanase + Glucanase & 45.72 & 14.00 \\
\hline
\end{tabular}

The voluntary consumption of the diet by the broilers could reflect the amount of energy in the diet. According to Ferket and Gernat (Ferket \& Gernat, 2006), broilers are unable to adequately reduce food intake when there are higher energy intakes, with heavier breeds tending to maintain feed intakes regardless of the energy content in the diet. The cause of this inability is most likely associated with genetic improvement programs aimed at hyperphagia, which is associated with high muscle tissue gains in commercial broiler strains (Barbato, 1994).

For animals to reach their optimum potential, it is necessary that their diets supply the amount of nutrients required for the maintenance of the organism and a surplus for deposition of muscle tissue. In this study, diets positive control (each phase), were formulated and aimed at the growth of male broilers with regular performance according to Brazilian Tables for Poultry and Swine (2011), and it was expected that those animals had nutritional requirements and performance responses according to this category(values for the feed intake [g/day] and weight gain [g/day], respectively, per phase were: 1 to 7 days - 23.0 and 19.6; 8 to 21 days 65.8 and $45.8 ; 22$ to 33 days - 137 and $77.6 ; 34$ to 42 days - 181 and 87). However, the development of the broilers in this study was greater than that reported in the Brazilian Tables for Poultry and Swine (2011) when BW, DWG, and FI were compared, with an increase of $18 \%$ in BW, $11 \%$ in DWG, and almost $2 \%$ in $\mathrm{Fl}$. This should be considered when evaluating the FCR results.

The supplementation of Phytase $\left(R_{-} 70+P\right)$ and phytase + carbohydrase $\left(R \_100+P+X G\right)$ in diets with reduced $M E$, resulted in feed conversion equivalent to the positive control in the periods of $1-7,1-28$, and 1-35 days. However, in the periods of 1-14, $1-21$, and $1-42$ days, only the treatment $R \_70+P$ showed a feed conversion equivalent to the positive control (Table 3). A comparison of the results found in this study with those expected for male broilers with regular performance showed that the highest growth rates were obtained at 1-14 and 1-21 days of age and that the BW, DWG, and FI values were higher than expected, reaching $21 \%, 13 \%$, and $6 \%$, respectively.

Providing energy and nutrient deficient diets in the initial growth stages has a negative impact on the growth rate and performance indices of broilers. Therefore, it can be assumed that the nutritional reductions in the experimental diets of 70 and 100 $\mathrm{kcal} / \mathrm{kg}, 0.16 \% \mathrm{Ca}$, and $0.15 \%$ AP were even more restrictive, as the development of the animals was greater than expected. This fact could explain the lack of effect of supplementing phytase + carbohydrases ( $\left.R \_100+P+X G\right)$ on FCR in the periods of 1-14 and $1-21$ days, as this treatment had the highest restriction on metabolizable energy (100 kcal $/ \mathrm{kg})$.

Some studies have evaluated the use of phytase associated with carbohydrases, mostly in diets with high quantities of NSPs, such as wheat, rice, and barley-based diets (Ravindran et al., 1999; Cowieson \& Adeola, 2005; Olukosi \& Adeola, 2008), and the effect of carboydrase had no obvious effect on either P or Ca digestibility (Cowieson \& Adeola, 2005). This could be related to the composition of the main cereal ingredient which was corn, a feed ingredient with a low concentration of arabinoxylan (Choct, 1997). Therefore, the potential for xylanase to improve $P$ digestibility was somewhat lower than would be the case in a wheat-based diet.

For some time, it was considered that diets based on corn and soybean meal did not cause digestive issues in poultry, and, thus, the use of exogenous enzymes was considered unnecessary in these cases (Zou et al., 2013). However, these products contain considerable amounts of NSPs, such that using carbohydrases may have a positive impact on animal performance. Schramm et al. (2017) affirmed that the presence of phytase, in a complete corn/soy-based diet, has a potentiating effect for exogenous xylanase. In our study, the performance results were improved in broilers fed diets containing nutritional reductions and enzymatic supplementation with carboydrases, showed the action of this enzyme. 
Table 3 - Performance of broilers fed diets with different energy, Ca, and AP content and supplemented or not with exogenous enzymes (mean \pm standard deviation).

\begin{tabular}{|c|c|c|c|c|c|}
\hline Days & Treatment $^{1}$ & $\begin{array}{r}\text { BW } \\
\text { (g) }\end{array}$ & DWG (g/broiler/day) & FI (g/broiler/day) & $\begin{array}{c}F C R \\
(\mathrm{~g} / \mathrm{g}) \\
\end{array}$ \\
\hline \multirow{6}{*}{$1-7$} & PC & $200.11 \pm 8.60 a b$ & $21.87 \pm 0.99 a b$ & $21.52 \pm 0.93 a$ & $0.984 \pm 0.02 c$ \\
\hline & R_70 & $192.88 \pm 6.78 b$ & $20.85 \pm 0.64 c$ & $21.28 \pm 0.65 a$ & $1.021 \pm 0.02 \mathrm{ab}$ \\
\hline & R_100 & $195.40 \pm 7.95 a b$ & $21.20 \pm 0.99 b c$ & $21.75 \pm 0.99 a$ & $1.025 \pm 0.02 a$ \\
\hline & R_70+P & $200.93 \pm 5.65 a b$ & $21.99 \pm 0.74 a b$ & $21.46 \pm 1.18 \mathrm{a}$ & $0.983 \pm 0.03 c$ \\
\hline & R_100+P+XG & $202.09 \pm 9.93 \mathrm{a}$ & $22.15 \pm 1.12 \mathrm{a}$ & $22.04 \pm 1.30 \mathrm{a}$ & $0.994 \pm 0.02 b c$ \\
\hline & $p^{*}$ & 0.008 & $<0.001$ & 0.323 & $<0.0001$ \\
\hline \multirow{6}{*}{$1-14$} & PC & $563.27 \pm 14.70 \mathrm{a}$ & $36.87 \pm 0.87 a$ & $42.63 \pm 0.95 a b$ & $1.156 \pm 0.01 \mathrm{~d}$ \\
\hline & R_70 & $528.05 \pm 27.65 b$ & $34.36 \pm 1.81 \mathrm{~b}$ & $41.38 \pm 1.55 b$ & $1.205 \pm 0.02 \mathrm{ab}$ \\
\hline & R_100 & $529.13 \pm 18.79 b$ & $34.44 \pm 1.18 b$ & $42.06 \pm 1.35 a b$ & $1.221 \pm 0.02 \mathrm{a}$ \\
\hline & $R \_70+P$ & $557.56 \pm 18.11 \mathrm{a}$ & $36.47 \pm 1.14 a$ & $42.82 \pm 1.08 a b$ & $1.174 \pm 0.02 \mathrm{~cd}$ \\
\hline & $R \_100+P+X G$ & $561.07 \pm 25.22 \mathrm{a}$ & $36.72 \pm 1.64 \mathrm{a}$ & $43.49 \pm 1.91 \mathrm{a}$ & $1.184 \pm 0.01 b c$ \\
\hline & $p^{*}$ & $<0.0001$ & $<0.0001$ & 0.001 & $<0.0001$ \\
\hline \multirow{6}{*}{$1-21$} & PC & $1126.43 \pm 25.30 \mathrm{a}$ & $51.40 \pm 1.11 \mathrm{a}$ & $63.81 \pm 1.13 \mathrm{a}$ & $1.241 \pm 0.01 \mathrm{~d}$ \\
\hline & R_70 & $1034.92 \pm 38.82 b$ & $47.04 \pm 1.75 b$ & $60.89 \pm 2.16 b$ & $1.294 \pm 0.02 b$ \\
\hline & R_100 & $1037.69 \pm 29.00 \mathrm{~b}$ & $47.17 \pm 1.28 b$ & $62.05 \pm 1.68 b$ & $1.315 \pm 0.02 \mathrm{a}$ \\
\hline & $R \_70+P$ & $1111.24 \pm 30.15 \mathrm{a}$ & $50.67 \pm 1.36 a$ & $63.81 \pm 1.36 \mathrm{a}$ & $1.259 \pm 0.01 \mathrm{~cd}$ \\
\hline & $R \_100+P+X G$ & $1119.12 \pm 36.56 \mathrm{a}$ & $51.05 \pm 1.63 a$ & $64.91 \pm 1.97$ a & $1.271 \pm 0.01 \mathrm{c}$ \\
\hline & $p^{\star}$ & $<0.0001$ & $<0.0001$ & $<0.0001$ & $<0.0001$ \\
\hline \multirow{6}{*}{$1-28$} & PC & $1796.85 \pm 38.26 \mathrm{a}$ & $62.49 \pm 1.34 \mathrm{a}$ & $82.87 \pm 1.63 a b$ & $1.326 \pm 0.01 c$ \\
\hline & R_70 & $1682.51 \pm 55.74 b$ & $58.41 \pm 1.91 b$ & $79.33 \pm 2.63 c$ & $1.358 \pm 0.01 \mathrm{~b}$ \\
\hline & R_100 & $1680.11 \pm 52.37 b$ & $58.32 \pm 1.79 b$ & $80.92 \pm 2.33 b c$ & $1.387 \pm 0.02 \mathrm{a}$ \\
\hline & R_70+P & $1788.60 \pm 69.71 \mathrm{a}$ & $62.20 \pm 2.45 \mathrm{a}$ & $83.09 \pm 1.91 a b$ & $1.336 \pm 0.02 c$ \\
\hline & R_100+P+XG & $1797.91 \pm 64.48 \mathrm{a}$ & $62.53 \pm 2.21 \mathrm{a}$ & $84.06 \pm 2.54 \mathrm{a}$ & $1.344 \pm 0.01 b c$ \\
\hline & $p^{*}$ & $<0.0001$ & $<0.0001$ & $<0.0001$ & $<0.0001$ \\
\hline \multirow{6}{*}{$1-35$} & PC & $2578.80 \pm 60.15 \mathrm{a}$ & $72.33 \pm 1.72 \mathrm{a}$ & $101.37 \pm 2.00 \mathrm{ab}$ & $1.401 \pm 0.02 b$ \\
\hline & R_70 & $2440.97 \pm 79.12 b$ & $68.40 \pm 2.20 \mathrm{~b}$ & $97.58 \pm 3.10 c$ & $1.426 \pm 0.02 b$ \\
\hline & R_100 & $2407.25 \pm 62.30 \mathrm{~b}$ & $67.43 \pm 1.72 b$ & $98.98 \pm 2.62 b c$ & $1.467 \pm 0.02 \mathrm{a}$ \\
\hline & R_70+P & $2563.38 \pm 62.30 \mathrm{a}$ & $71.89 \pm 1.76 a$ & $101.86 \pm 2.00 \mathrm{a}$ & $1.417 \pm 0.01 b$ \\
\hline & R_100+P+XG & $2592.92 \pm 93.66 \mathrm{a}$ & $72.73 \pm 2.62 \mathrm{a}$ & $103.22 \pm 2.35 \mathrm{a}$ & $1.419 \pm 0.03 b$ \\
\hline & $p^{*}$ & $<0.0001$ & $<0.0001$ & $<0.0001$ & $<0.0001$ \\
\hline \multirow{6}{*}{$1-42$} & PC & $3364.30 \pm 67.98 \mathrm{a}$ & $78.98 \pm 1.60 \mathrm{a}$ & $118.44 \pm 2.17 \mathrm{bc}$ & $1.499 \pm 0.03 b$ \\
\hline & R_70 & $3226.84 \pm 85.92 b$ & $75.71 \pm 2.01 b$ & $115.12 \pm 3.18 d$ & $1.520 \pm 0.02 \mathrm{ab}$ \\
\hline & R_100 & $3219.56 \pm 82.94 b$ & $75.53 \pm 1.94 b$ & $116.80 \pm 2.92 \mathrm{~cd}$ & $1.546 \pm 0.03 \mathrm{a}$ \\
\hline & R_70+P & $3357.18 \pm 98.86 a$ & $78.81 \pm 2.34 \mathrm{a}$ & $120.05 \pm 2.89 a b$ & $1.523 \pm 0.02 \mathrm{ab}$ \\
\hline & R_100+P+XG & $3385.52 \pm 102.98 a$ & $79.48 \pm 2.40 \mathrm{a}$ & $121.38 \pm 2.85 a$ & $1.527 \pm 0.02 \mathrm{a}$ \\
\hline & $p^{\star}$ & $<0.0001$ & $<0.0001$ & $<0.0001$ & $<0.001$ \\
\hline
\end{tabular}

Body weight (BW); Daily weight gain (DWG); Feed intake (FI); Feed conversion ratio (FCR). ${ }^{1}$ Treatments: $\mathrm{PC}=$ positive control - basal diet (BD) - corn and soybean meal; $\mathrm{R} \_70=\mathrm{BD}$ with reductions of $70 \mathrm{kcal} / \mathrm{kg}$ and $0.16 \% \mathrm{Ca}$ and $0.15 \% \mathrm{AP} ; \mathrm{R} \_100=\mathrm{BD}$ with reductions of $100 \mathrm{kcal} / \mathrm{kg}$ and $0.16 \% \mathrm{Ca}$ and $0.15 \% \mathrm{AP} ; \mathrm{R} \_70+\mathrm{P}=\mathrm{BD}$ with reductions of $70 \mathrm{kcal} / \mathrm{kg}$ and $0.16 \% \mathrm{Ca}$ and $0.15 \% \mathrm{AP}+$ phytase (500 FTU/kg); R_100 + P + XG = BD with reductions of $100 \mathrm{kcal} / \mathrm{kg}$ and $0.16 \% \mathrm{Ca}$ and $0.15 \%$ AP + phytase (500 FTU/kg) xylanase (560 $\mathrm{TXU} / \mathrm{kg})+$ glucanase $(250 \mathrm{TGU} / \mathrm{kg}) ;{ }^{*}$ probability; **means followed by different lowercase letters in the column differ from each other according to the Tukey's test at $5 \%$ probability.

\section{Carcass yield and Production costs}

In the evaluation of cold carcass yield, there was no significant difference between treatments $(P=$ $0.21)$, and the mean values found for each treatment were: $(P C)=79.94 \pm 0.83 ;\left(R \_70\right)=79.05 \pm 0.89 ;\left(R_{-} 100\right)$ $=79.07 \pm 1.39 ;\left(R \_70+P\right)=79.54 \pm 1.07 ;\left(R \_100+P+\right.$ $X G)=79.77 \pm 0.77$.

The positive control treatment came to a higher production cost (USD/ton chilled carcass), and this cost differed significantly from that of treatment $R_{-} 100+P$ $+X G$ (Figure 1).
The cost analysis showed that one ton of chilled carcasses of broilers fed the positive control diet cost USD 782 to produce, whereas the production cost for broilers fed the R_100+P+XG diet was USD 752, i.e., a reduction of USD 30.0 in the production cost at the end of the process. Treatments containing nutritional reductions without enzyme supplementation ( $R \_70$ and $\left.R \_100\right)$ presented intermediate production costs, on matching their means to the PC and $R \_100+P+X G$.

The use of hybrid phytase (500 FTU/ $/ \mathrm{kg}$ ) alone is effective to maintain the productive performance of 


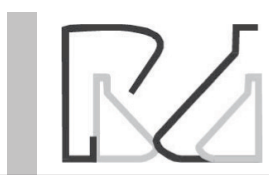

$P-$ value $=0.05$

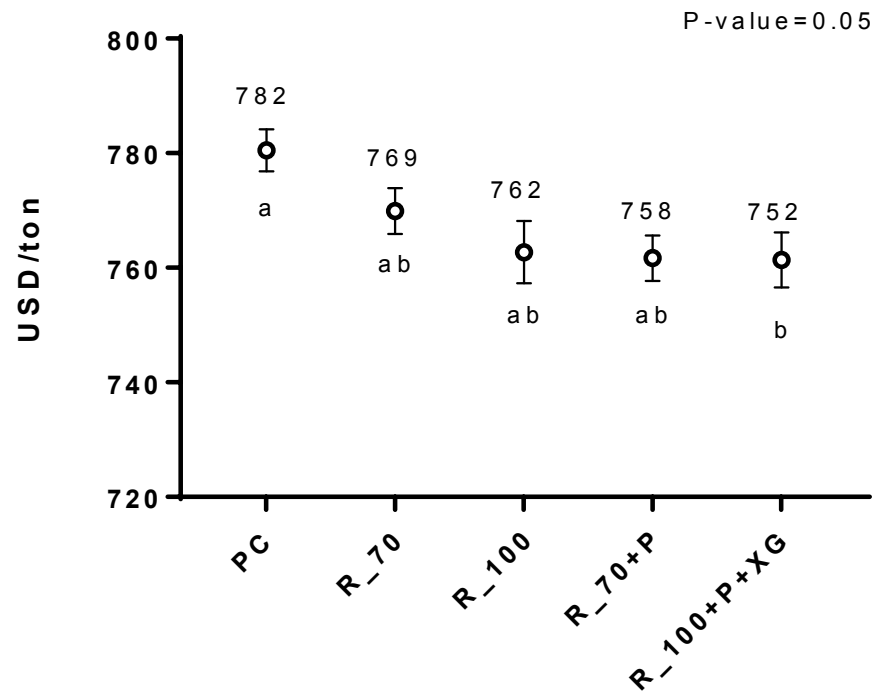

Treatm ent

Figure 1 - Production costs of chilled carcasses of broilers fed diets with nutritional reductions supplemented or not with enzymes.

$P C=$ positive control - basal diet $(B D)$ - corn and soybean meal; $R_{-} 70=B D$ with reductions of $70 \mathrm{kcal} / \mathrm{kg}$ and $0.16 \% \mathrm{Ca}$, and $0.15 \% \mathrm{AP} ; \mathrm{R} \_100=\mathrm{BD}$ with reductions of 100 $\mathrm{kcal} / \mathrm{kg}, 0.16 \% \mathrm{Ca}$ and $0.15 \% \mathrm{AP} ; \mathrm{R} \_70+\mathrm{P}=\mathrm{BD}$ with reductions of $70 \mathrm{kcal} / \mathrm{kg}$ and $0.16 \% \mathrm{Ca}$, and $0.15 \% \mathrm{AP}$ + phytase $(500 \mathrm{FTU} / \mathrm{kg}) ; \mathrm{R} \_100+\mathrm{P}+\mathrm{XG}=\mathrm{BD}$ with reductions of $100 \mathrm{kcal} / \mathrm{kg}, 0.16 \% \mathrm{Ca}$ and $0.15 \%$ AP + phytase $(500 \mathrm{FTU} / \mathrm{kg})+$ xylanase $(560$ $\mathrm{TXU} / \mathrm{kg})+$ glucanase $(250 \mathrm{TGU} / \mathrm{kg})$. Means followed by different lowercase letters differ according to Tukey's test $(p<0.05)$.

broilers fed diets with a reduction of up to $70 \mathrm{kcal} / \mathrm{kg}$, $0.16 \% \mathrm{Ca}$, and $0.15 \%$ AP during a 42 -day period. The combination of the hybrid phytase (500 FTU/kg) with xylanase (560 TXU/kg) and glucanase (250 TGU/kg) is effective to maintain the body weight and daily weight gain when there are nutritional reductions in the diet of broilers of $100 \mathrm{kcal} / \mathrm{kg}, 0.16 \% \mathrm{Ca}$, and $0.15 \%$ AP.

Broilers fed a specific enzyme diet (500 FTU/ $\mathrm{kg}$ phytase + $560 \mathrm{TXU} / \mathrm{kg}$ xylanase + $250 \mathrm{TGU} / \mathrm{kg}$ glucanase) together with a diet with a nutritional reduction of $100 \mathrm{kcal} / \mathrm{kg}, 0.16 \% \mathrm{Ca}$, and $0.15 \% \mathrm{AP}$ for a period of 42 days showed the lowest production cost in USD/ton chilled carcass.

\section{ACKNOWLEDGEMENTS}

The authors would like to thank BASF SA for making this research possible. We are grateful for the support from the Coordination for the Improvement of Higher Education Personnel - Brazil (CAPES) - Funding Code 001.Embrapa Swine and Poultry.We would also like to thank Editage (www.editage.com) for the English language editing.

\section{REFERENCES}

Barbato GF. Genetic control of food intake in chickens. The Journal of Nutrition 1994;124(suppl 8):1341S-1348S.

\section{Hybrid Phytase and Carbohydrases in Corn and Soybean Meal-Based Diets for Broiler Chickens: Performance and Production Costs}

Bedford MR. Exogenous enzymes in monogastric nutrition - Their current value and future benefits. Animal Feed Science and Technology 2000;86(1-2):1-13.

Brazilian Tables for Poultry and Swine. Composition on feedstuffs and nutricional requirements. $3^{\text {rd }}$ ed. Viçosa: Editora UFV; 2011. 251p.

Canever MD, Talamini DJD, Campos C, Santos Filho Jl dos, Gomes MF. Custos de produção do frango de corte no Brasil e na Argentina [Documentos, 39]. Concórdia: Embrapa; 1996.

Choct M. Feed non-starch polysaccharides: chemical structures and nutritional significance. Feed Milling International 1997;6:13-27.

Cowieson AJ, Adeola O. Carbohydrases, protease, and phytase have an additive beneficial effect in nutritionally marginal diets for broiler chicks. Poultry Science 2005;84(12):1860-1867.

Ferket PR, Gernat AG. Factors that affect feed intake of meat birds: A review. International Journal of Poultry Science 2006,5(10):905-911.

Girotto AF, Protas JF da S. Custo de produção de suínos para abate: uma revisão [Documentos. 18]. Concórdia: EMBRAPA-CNPSA; 1994.

Girotto AF, Santos Filho Jl dos. Custo de produção de suínos [Documentos, 62] Concórdia: Embrapa Suínos e Aves; 2000.

Girotto AF, Souza MVN de. Metodologia para o cálculo do custo de produção de frango de corte - versão 1 [Documentos, 109]. Concórdia: Embrapa Suínos e Aves; 2005.

Juanpere J, Pérez-Vendrell AM, Angulo E, Brufau J. Assessment of potential interactions between phytase and glycosidase enzyme supplementation on nutrient digestibility in broilers. Poultry Science 2005;84(4):571580 .

Krabbe EL, Surek D, Avila VS, Ruiz JH, Ader P. Effecty of dietary Natugrain TS enzyme supplementation on broiler diet digestibility. Proceedings of the PSA Annual Meeting; 2014; Corpus Christi. Texas; 2014.

Kocher A, Choct M, Ross G, Broz J, Chungt TK. Effects of enzyme combinations on apparent metabolizable energy of corn-soybean meal- based diets in broilers. The Journal Applied Poultry Research 2003; 12:275-283.

Lu H, Adedokun SA, Preynat A, Legrand-Defretin V, Geraert PA, Adeola $\mathrm{O}$, et al. Impact of exogenous carbohydrases and phytase on growth performance and nutrient digestibility in broilers. Canadian Journal of Animal Science 2013;93(2):243-249.

Maenz DD. Enzymatic and other characteristics of phytases as they relate to their use in animal feeds. Enzymes in farm animal nutrition. Wallingford: CABI Publishing; 2001.

Meng $X$, Slominski BA. Nutritive values of corn, soybean meal, canola meal, and peas for broiler chickens as affected by a multicarbohydrase preparation of cell wall degrading enzymes. Poultry Science 2005;84(8):1242-1251.

Miele M, Martins FM, Santos Filho JI, Sandi AJ. Metodologia para o cálculo do custo do produção de frango de corte - Versão 2. Concórdia: Embrapa Suínos e Aves; 2010.

Olukosi OA, Adeola O. Whole body nutrient accretion, growth performance and total tract nutrient retention responses of broilers to supplementation of xylanase and phytase individually or in combination in wheat-soybean meal based diets. The Journal of Poultry Science 2008:45(3):192-198

Protas JF. Custo médio de produção de suínos para abate [Comunicado Técnico, 72]. Concórdia: Embrapa-CNPSA; 1983. 
R Core Team. R: a language and environment for statistical computing. Vienna: R Foundation for Statistical Computing; 2015. Available from: http://www.R-Project.Org/.

Ravindran V, Selle PH, Bryden HL. Effects of phytase supplementation, individually and in combination, with glycanase, on the nutritive value of wheat and barley. Poultry Science 1999;78(11):1588-1595.

Romero LF, Sands JS, Indrakumar SE, Plumstead PW, Dalsgaard S, Ravindran $V$. Contribution of protein, starch, and fat to the apparent ileal digestible energy of corn- and wheat-based broiler diets in response to exogenous xylanase and amylase without or with protease. Poultry Science 2014;93(10):2501-2513.

Santos Filho Jl dos, Canever MD, Chiucheta O, Talamini DJD. Aspectos econômicos e viabilidade da criação de frangos nos sistemas convencional e automatizado. Anais do Simpósio Internacional Sobre Ambiência e Sistemas de Produção Avícola; 1998; Concórdia. Anais. Concórdia, Santa Catarina. Brasil; 1998 p.7-17.
Selle PH, Ravindran V. Microbial phytase in poultry nutrition. Animal Feed Science and Technology 2007;135(1-2):1-41.

Schramm VG, Durau JF, Barrilli, LNE, Sorbara JOB, Cowieson AJ, Felix AP, et al. Interaction between xylanase and phytase on the digestibility of corn and a corn / soy diet for broiler chickens. Poultry Science 2017;96(5):1204-1211.

Torrallardona D, Ader P, Coelho M. Validation of the extended matrix values for energy and amino acids of a new novel 6-phytase, Natuphos $E$, in weaned piglets. Journal of Animal Science 2017;95(suppl 2):117-118.

Woyengo TA, Nyachoti CM. Review: supplementation of phytase and carbohydrases to diets for poultry. Canadian Journal of Animal Science 2011;91:177-192.

Zou J, Zheng P, Zhang K, Ding X, Bai S. Effects of exogenous enzymes and dietary energy on performance and digestive physiology of broilers. Journal of Animal Science and Biotechnology 2013;4(1):1. 